\title{
Gender Role Attitudes among Higher Education Students in a Borderland Central-Eastern European Region called 'Partium'
}

HaJNALKa FÉNYES ${ }^{1}$

$\approx$ In this paper, we examine the attitudes towards gender roles among higher education students in a borderland Central-Eastern European region. We used the database of 'The Impact of Tertiary Education on Regional Development' project $(\mathrm{N}=602,2010)$. We intend to determine what kind of attitudes towards gender roles the students identify themselves with, what affects these attitudes (gender, faculty type, social background of students, locality type, religiosity), and finally what kind of educational policy implications could be relevant concerning our findings. We have used cluster analysis and a logistic regression model, and formulated several hypotheses that were controlled by these methods. Our results show that there are a large number of students who belong to the more traditional attitude cluster in this region, but women more frequently identify themselves with modern gender roles than men do. The faculty-type effect has only been partly detected. We have found that with 'male-dominated' majors, both women and men identify themselves with more traditional attitudes and that with 'female-dominated' majors all students have more modern attitudes. The effect of social background is contradictory. Those whose parents had larger numbers of books had increased modern attitudes, but the factor 'regular financial problems in the family' also increased it. Our next result is that students who live in villages are not more traditional than others, because they live in cities during their studies. Our final result is that churchly religious students think more traditionally regarding gender roles than others do, but those who are religious in their own way do not.

Keywords: gender role attitudes, higher education students, quantitative regional research

1 University of Debrecen, Department of Sociology and Social Policy, Hungary; fenyesh@gmail.com 


\section{Spolne vloge med visokošolskimi študenti na območju osrednje in vzhodne evropske regije, imenovane 'Partium'}

HaJNALKa FÉNYES

$\approx$ V prispevku preučujemo odnose do spolnih vlog med visokošolskimi študenti na območju osrednje in vzhodne evropske regije. Uporabili smo podatke, ki so bili pridobljeni v okviru projekta Vpliv terciarnega izobraževanja na razvoj regije $(\mathrm{N}=602,2010)$. Namen je bil ugotoviti, s katerimi spolnimi vlogami se študentje identificirajo, kaj vpliva na te vloge (spol, vrsta fakultete, socialno ozadje študentov, vrsta lokacije, religioznost) in - končno - katere edukacijsko-politične implikacije bi lahko sledile iz naših ugotovitev. Postavljene hipoteze smo preverili s pomočjo klastrske analize in logističnega regresijska modela ter oblikovali več hipotez, ki smo jih preverili s temi metodami. Rezultati kažejo, da je v tej regiji veliko študentov, ki sodijo $\mathrm{v}$ bolj tradicionalno naravnan klaster, vendar se ženske pogosteje identificirajo z modernimi spolnimi vlogami kot moški. Vpliv vrste fakultete je bil le delno zaznan. Ugotovili smo, da se pri pretežno »moških « študijih ženske in moški identificirajo z bolj tradicionalnimi vlogami, pri pretežno »ženskih« pa se oboji identificirajo z modernejšimi vlogami. Vpliv socialnega ozadja je protisloven. Študentje, katerih starši so imeli veliko knjig, so imeli izrazito moderna stališča, vendar pa to povečuje tudi faktor "pogoste finančne težave v družini«. Naslednja ugotovitev je, da študentje, ki živijo na vasi, niso bolj tradicionalni od tistih, ki med študijem živijo v mestih. Naša zadnja ugotovitev je, da tradicionalno religiozni študentje razmišljajo o spolnih vlogah bolj tradicionalno kot drugi, vendar ne tudi tisti, ki so religiozni na svoj lasten način.

Ključne besede: spolne vloge, visokošolski študentje, kvantitativna regionalna raziskava 


\section{Introduction}

Our goal in this paper is to examine the attitudes toward gender roles of higher education students in a borderland Central-Eastern European region. In the theoretical part of the paper, we deal with gender roles in general, with the socialisation to gender roles, and with the changes in the trends of gender role attitudes in Hungary. In the empirical part, we create clusters of students based on the level of agreement with the ten different statements about gender roles, using the SPSS statistical software, and we explore the effect of gender, faculty type ('female dominated' or 'male dominated'), the social background of students (measured by the cultural and the material capital of students) and religiosity on the gender role attitudes of students (more traditional or more modern) in the frame of a logistic regression model. We have formulated several hypotheses, and we will control them by using this quantitative method. Finally, in the summary we attempt to show some educational policy implications of our results.

\section{Gender roles}

According to Linton's definition, a 'role' is a behaviour pattern belonging to a particular social status (see Buda, 1985). The role regulates the various norms that define the behaviour in various social positions and statuses in contrast with other status holders; thus, role-behaviour is an interactive process. 'Gender roles are the roles that men and women are expected to occupy based on their sex' (Blackstone, 2003, p. 337). 'Woman's role is a set of primarily feminine behavioral features and norms [...] rules and prescriptions, which are related to the behavior and communication of women with men and other role partners' (Buda, 1985, p. 100).

According traditional gender role perceptions, women should behave in ways that are nurturing, and men should be the head of their household and should provide financial support for the family. Modern gender roles perceptions suggest an alternative view. They suggest that individuals' behaviour should not be determined only by their sex and that there should be more egalitarian relationships between men and women. Individuals should have the right to choose the roles they want to occupy and to what extent these roles are associated with their sex. (Blackstone, 2003)

Functionalists (Parsons \& Bales, 1955) propose that a division of labour according to gender is inevitable and beneficial for society. The role of men is instrumental (to provide sustenance), whereas the role of women is expressive 
(to provide emotional support). However, in modern societies, there tend to be increasingly fewer jobs that women are not able to do; thus, the division of labour according to gender is not inevitable.

Inglehart and Norris (2003) examine how the traditional gender role attitudes changed in 70 countries in the $20^{\text {th }}$ century. Their finding is that socioeconomic development (the shift from agrarian societies to industrialised societies, and the shift from industrial towards post-industrial societies) transforms cultural attitudes towards gender equality. As a result of modernisation, the traditional family model is declining, and there has been a rise of gender equality. Richer, post-industrial societies have much more egalitarian gender role attitudes than poorer, agrarian, industrial ones do.

The reasons for the changes in gender roles are women's increasing participation in education and the labour market, and the increasing secularisation, '[...] which eroded the traditional religious base of the many moral absolutes associated with the family' (Scott, 2006, p. 3). Increasing individual autonomy and female emancipation also have an effect on women's roles. However, the results of Scott, based on European Value Surveys, show that nowadays most countries still regard marriage and family as essential institutions. (Scott, 2006)

Fortin (2005) shows that traditional gender role attitudes remaining popular in developed countries after World War II may be due to the widespread acceptance of religious conservatism, and this could be one of the cause of the slowdown in a decrease in the wage gap between men and women and the slowdown in the increase in women's employment rates. Vella (1994) emphasises that the traditional gender role attitudes of women result in the reduction of women's human capital investment, labour supply and rates of return to education and that these attitudes are determined outside the educational process. Simultaneously, based on a deeper analysis of Thornton and YoungDeMarco (2001) and Brewster and Padavic (2000), in the US, there were rapid changes in gender role attitudes (measured by changes in opinions about women's and men's work and family responsibilities) between 1960 and 1980, but in the 1980 ond 1990 s the changes were slower; moreover, in the late 1990s, gender role attitudes were becoming slightly more conservative than before. This could be because there was a large influx of women into the labour force after World War II, and the differences in attitudes between cohorts tend to become less pronounced later. Another reason for the slower attitude changes could be that nowadays conservatism has become more popular (see above), and this has confirmed traditional attitudes towards gender roles. Nevertheless, Brewster and Padavic (2000) also emphasise that recent structural changes, such as the further rapid influx of women into the labour force, women's increased 
proportional contribution to family incomes, an increase in the education level of the population and fathers' increased participation in child care could moderate the slowdown in the changes in gender role attitudes. All things considered, they conclude that the liberalisation of gender roles has not been finished yet due to these facts.

The attitude of the young generation is changing more quickly than that of their elders. Based on the findings of Tinklin et al. (2005), 16-17-year-old people believed that it is beneficial for both genders to obtain higher qualifications and good careers and that childcare should be a joint responsibility. However, they were still choosing gender-typical education lines and occupations, so their behaviour remains gender-typical. (Tinklin et al., 2005)

Recently, gender-behavioural norms have become more symmetrical, and men's roles have also been changing, but the question arises whether typical feminine roles could be fulfilled by men. The opinion of the European population is not optimistic concerning the involvement of men in family chores and care; in particular, men's opinions are changing slowly (Scott, 2006).

Researchers have shown that mothers are less likely to work than nonmothers due to their competing work roles and family roles, although the fathers' behaviour could be different. The good-provider role model (traditional model) predicts that fathers will work more than non-fathers, while the involved-father model (men are increasingly involved in nurturing and rearing children, which can be called the 'new fatherhood') predicts that fatherhood might encourage men to work less. Kaufman and Uhlenberg (2000) have found evidence for both models. It can be supposed that the two models act simultaneously and that the actors can choose which model is suitable for the family, depending on circumstances. Zuo and Tang (2000) showed that a lower breadwinner status of men also promotes a more egalitarian ideology among men and that men actually benefit from their wives' financial contribution to the family rather than feeling of a loss of their masculine identity and suffering from the fact that their wives have less time for domestic chores.

On the whole, although men's identity is rarely based on gender roles (their occupational role much more essential), men's gender role is as complex as the women's, which can also be the source of various tensions. (Buda, 1985; H.Sas, 1984; Somlai, 1997)

\section{Socialisation to gender roles}

Socialisation in general - but also socialisation to gender roles - happens in several places. Primary, i.e. early, socialisation takes place in the family, where boys and girls normally wear different clothes; their hairstyle, toys, and 
activities (in the household) and treatment and expectations of the parents are also different. In the socialisation process, peer groups have a highly significant role, whose impact in the formation of gender roles seems to be more pronounced than that of the family. Early friendship ties between the same genders are important as children come to be aware of gender roles through imitation (typically masculine and feminine activities and career orientations are being formed at this stage). These days, even mass media play a significant part in the socialisation to gender roles, transmitting the predominant role models by means of soap operas, advertisements, tabloids and films. (Somlai, 1997)

Secondary socialisation also takes place in the education system. Gender roles are acquired mainly through formal and informal teacher and student interactions. Although gender stereotypes seem to be on the decrease in the curriculum, they tend to appear in the 'hidden' curriculum ${ }^{2}$ (different expectations by teachers, school regulations according to gender) (Szabó, 1988). According to feminist researchers, teachers are more permissive and biased toward boys in a positive way; they praise them more frequently and they attribute their achievement to their intelligence, while in the case of girls it is attributed to their diligence. Another question to be answered is whether the fact that the majority of teachers are women nowadays is favourable to either boys or girls. It is commonly thought that the evaluation system of the high schools favours girls and this may be the reason for their better educational attainment, which does not necessary mean that the feminisation of the teaching profession is the only cause of the better achievement of girls. (We think that this is a complex question; see Fényes (2010b) for the possible reasons for the better achievement of girls in high schools.) Researchers have also suggested that due to the different learning methods of boys and girls, different curricula should be elaborated according to gender and that in some educational areas segregated education would be desirable. The supporters of segregation also emphasise that at the ages of 6 and 7 girls' neurological development is faster than that of boys (although by the age of ten boys tend to have compensated for this) and that girls have better verbal skills, whereas boys have better mathematical and technical skills, based on the results of PISA tests in Hungary and in the OECD countries (see Fényes, 2010b for the details). Furthermore, researchers of education have also cited the impact of textbooks in transmitting role models. Normally, boys are portrayed in these books as independent-minded, whereas girls are passive (Háber \& H. Sas, 1980; Kereszty, 2005).

2 The 'hidden curriculum' can be defined as the non-intentional message of formal education. It includes latent messages, which are mediated to students, these play an important role in the reproduction of social inequalities in the school as well (Saha, 1997). 
We can suppose that, in general, the effect of schools on gender role is smaller than the effect of peers and family. An American study showed that only minor changes in girls' gender role attitudes due to the effect of the environment in elementary schools (Adler, Kless, \& Adler, 1992). Gender role attitudes are more related to the family and background characteristics than to the educational attainment. (Vella, 1994)

Astin and Kent (1983) examined the effect of higher education institutions on the self-esteem and value preferences of men and women in the US. This type of research is especially significant because the formation of gender roles is strongly related to identity and self-evaluation. One of their research questions is whether there is a convergence of interests and attitudes between men and women due to college or, as Astin (1977) showed, colleges do not serve to reduce most of the stereotypical differences between genders. Astin and Kent's results show that female freshmen had more positive self-image and more 'masculine' values in 1970 than previously and that in the 1970 s women's self-ratings also improved (though they still lagged behind men). With regards to the attitudes of men, in 1980 they valued the goal of raising a family slightly higher than they did in 1971, but men majoring in arts and humanities valued this goal less than other men did.

The gender role attitudes of higher education students could be related to the fact that in developed countries girls are in the majority in general high schools and higher education, and their social mobility is higher. The other field in which boys lag behind girls is efficacy in school. The results of Fényes (2010b) showed that girls were more successful in high schools in Hungary, but in higher education, according to some indicators of efficiency (publication activity during the studies, special college student status, $\mathrm{PhD}$ plans) boys have an advantage, which may predict their better position on the labour market.

\section{Gender roles in Central-Eastern Europe, focusing on the situation of Hungary}

After World War II, there was a massive influx of girls in secondary and tertiary education, but traditional feminine roles hardly changed. Women's access to high prestige jobs did not increase significantly, and traditional social relations remained very much the same. According to Pukánszky, the educational paths of boys and girls were different due to their choice of different careers. In the 1970s, increasing numbers of women took traditionally male jobs but this 'feminisation' has led to the loss of prestige and pay of these jobs. Women have been mostly employed in low prestige jobs and very few women can be found in 
managerial (CEO) positions. (Pukánszky, 2006)

In post-World War II in socialist countries, the dual-earner family model was prevalent, i.e. most of the women were full-time workers; nevertheless, most men and women identified themselves with traditional gender roles. The large labour market participation of women was not voluntary but rather out of necessity, because wages were generally low and there was a need for women's labour due to rapid industrialisation. Furthermore, the prevailing political ideology declared that women should work (even in hard manual jobs), and the emancipation and the higher level of education of women also affected the larger participation of women in the labour market. (Schadt, 2003)

After the political change in 1989, there was a significant decline in women's employment. The reason for this was that women could avoid unemployment by staying at home with children (full-time employment was no longer obligatory), and some women also chose to remain at home because their husbands had good salaries. The other reason for the decline in women's employment was that the political ideology had changed. The dual-income family model wavered, and the Christian Democratic conservative family model has become more popular. However, in some families, there is still a necessity for women's employment for financial reasons (poor or/and one-parent families) and the higher level of education and emancipation are also increasing the labour market participation of women after the change of economic systems.

In both 1974 and in 2001, Hungarians identified themselves with a conservative, family-centred mentality and, despite the rapid increase in women's education and labour market participation, the traditional division of labour in the family could still be found. Based on public opinion, most of the household duties remain the domain of women. (Pongráczné, 2005)

In Hungary in the 1990s, the number of people who agreed with that women should be employed decreased from $82 \%$ to $67 \%$, and the number of people who were of the opinion that women should be concerned mainly with child rearing and the household increased to $28 \%$. There was also an increase in the preference of part-time jobs (Frey, 2001). However, research by Gregor (2008) indicated that, at the turn of the millennium in post-socialist countries, women were much more likely to encounter conflicts between their family and job roles than women in Western European countries were, which may be due to a lower availability of part-time jobs.

According to H. Sas (1984), due to women's employment, gender stereotypes and gender roles have been changing, and some traditional masculine features have also been taken up by women, but only those with high qualifications and mainly in cities. It is mostly among intellectuals that the ideal of 
woman has altered. According to Pongráczné (2005), a comparative study in 12 countries showed that in Hungary the rate of those who agree with the opinion that it is up to the husband to provide the sustenance of the family and the woman's role is to look after the children and the household chores is rather high. However, the majority of the people in post-socialist countries also agreed with the fact that these days women are required to have a job because it is only this way that family needs can be provided. In general, based on the results of this comparative study, at the turn of the millennium, traditional roles were prevalent in Central-Eastern Europe.

Even nowadays, Hungarians are family- and child-centred, rather than work- and wage-earner-activity-centred; however, between 2000 and 2009, the importance of the wage earning activity of mothers slightly increased, and the importance of children and family decreased somewhat. Modern and mixed gender role attitudes have become more popular, and the acceptance of traditional gender roles is decreasing. Nevertheless, women's motherhood and family provider role remains a priority, and the traditional division of family roles is accepted by more than half of the examined population. It is also an intriguing result that gender role attitudes become more homogeneous according to the age, education and number of children during the examined period. However, there are still large gender differences in attitudes: women identify themselves with modern attitudes more frequently than men do, according to international findings (Pongráczné \& S. Molnár, 2011),

Among higher education students, even nowadays identification with modern gender roles is not complete; the traditional attitudes are still alive. Their affinity for modern attitudes is more in word than in deed (Fényes, 2010a, 2012). The young generation can be characterised by conservative attitudes towards gender roles, and contrary to Western countries, where the attitudes of old and young people differ markedly, in Hungary there is no significant difference in attitudes between the youth and elderly people. (Laki et al., 2008)

\section{Methods, databases and the examined variables}

In our quantitative empirical research, variance analysis (compare means runs), cluster analysis and logistic regression model were used via SPSS software. We used the database of the TERD research ('The Impact of Tertiary Education on Regional Development', supported by OTKA T-69160). In the sample, 602 Master's training (MA, MSc) first-year full-time students were surveyed (approximately two thirds of the full population). The sample is regional, as data were collected in the so-called Partium region. This is a historically 
cross-border region of Hungary, Romania and Ukraine. ${ }^{3}$ The data collection took place in the Hungarian-speaking tertiary-level institutions of the three countries in 2010. ${ }^{4}$ We asked students proportionately at different faculties, so the sample is representative with regard to the faculties (cases were weighted to ensure the representativity due to the unequal willingness to answer). Cluster sampling was performed; all the students at the chosen seminar groups (selected at random) were asked.

The examined variables were as follows: ten statements about gender roles (details to follow) (1: totally disagree, 2: disagree, 3: agree, 4: totally agree); students were clustered based on these variables. In the logistic regression model, the dependent variable was the gender role attitude cluster membership (o: more traditional, 1: more modern). The explanatory variables: GENDER (o: women, 1: men). FACTYPE (the percentage of women by the faculties), EDMOTHER (the students' mothers' years education completed), EDFATHER (the students' fathers' years of education completed), BOOKSPAR (1: the parents' number of books is over 100, o: less), DURCONS (possession of durable consumer goods of students' family index ${ }^{5} 1-10$ ), FIN1oYEARS (o: standard of living of the students' family is worse than 10 years before, based on the opinion of students, 1: better or similar), FINPROB (financial problems in the family: o: yes, regularly, 1: rarely or no), SETTYPE (o: village or farm, 1: town), REL$\mathrm{CHURCH}$ (1: churchly religious students, means that someone is following the instructions of their church, o: not), RELOWN (1: students religious in their own way, o: not).

\section{Indicators for traditional and modern gender role attitudes}

In the literature (Vella, 1994; Rice \& Coates, 1995; Bielby \& Bielby, 1992; Fortin, 2005; Brewster \& Padavic, 2000; Tallichet \& Willits, 1986), the most frequent indicators for gender role attitudes are the following: acceptance of the double-earner family model (in contrast to men's single breadwinner role) and agreement with the statement 'Mother's relationship with the children does

3 In present-day Hungarian usage, 'Partium' refers only to the Romanian part of the historical region, but we defined it differently, reflecting the historical usage of 'Partium'.

4 The institutions involved in the research: University of Debrecen (Hungary), Reformed Teacher Training College (Kölcsey), (Debrecen, Hungary), Nyíregyháza College (teacher training, health care) (Nyíregyháza, Hungary), II Rákóczi Ferenc Hungarian Teacher Training College of Transcarpathia (Beregszász, Ukraine). Partium Christian University (Oradea, Romania), University of Oradea (Oradea, Romania), Branch of Babes-Bolyai University in Satu Mare (Satu Mare, Romania).

5 The components of the index are: possession of flat, cottage, house, computer, internet subscription, hi-fi, air-conditioning, home movie equipment, car and plasma TV. 
not suffer if the mother is employed outside the home' show modern attitudes. A modern attitude could be also disagreement with the statements 'Being a housewife is just as fulfilling as working for pay' and 'If men and women are equally able to handle a job, the men should be hired'. A modern attitude is also reflected is disagreement with the statements 'Important decisions should be made by the husband rather than the wife' and 'It is more important for the wife to help her husband's career than to have one herself'. The agreement with the statement 'Husbands and wives should both do the housework' also reflects modern attitudes.

In our research, ten statements about gender roles were used (most of them were mentioned in the literature). Examining the other statements that were also mentioned in the literature will be the task of a following research project.

The modern attitudes were measured according to agreement with these statements:

1. The husband should significantly participate in rearing the children.

2. If the child is ill, the father can go on sick leave.

3. Both women and men should participate in assuring the sustenance of the family.

4. The cooperation of men and women is necessary in solving the problems of the family.

5. The household work should be shared by both the husband and the wife.

The traditional attitudes were measured by agreement with these statements:

1. It is the task of women to do the housework.

2. To assure the sustenance of the family is primarily the task of the husband.

3. The most important decisions in the family should be made by the husband.

4. Rearing children primarily is the task of women.

5. If the child is ill, the mother should go on sick leave.

The reliability of scales is quite large; concerning both scales, the Chronbach alpha is 0.795 . 


\section{Hypotheses}

Based on the findings of the literature our hypotheses are the following:

H1: Higher education students identify themselves with more modern gender roles than the whole population (this hypothesis can be only partly controlled).

H2: Among students, women identify themselves with more modern gender roles than men.

$\mathrm{H}_{3}$ : The faculty-type effect: in 'male-dominated' majors (where the participation of women is lower) women identify themselves with more modern gender roles than in 'female-dominated' majors (majors with a large female majority), and men identify themselves with more modern gender roles in 'female-dominated' majors than in 'male-dominated' majors.

H4a: Social background effect: students with disadvantageous social backgrounds (measured by their cultural and material capital) identify themselves with more traditional attitudes.

H4b: Social mobility hypothesis: students who will be first-generation professionals identify themselves with more modern gender roles than others.

$\mathrm{H}_{5}$ : Students who live in villages have more traditional gender role attitudes.

H6: The better social background of men moderates their more traditional gender role attitudes compared to women.

$\mathrm{H}_{7}$ : Religious students are characterised by more traditional gender role attitudes.

\section{Results}

At first, we compared the means of the agreement scales on gender role attitudes (on 10 statements) by gender; we then created clusters of students based on these attitudes. Finally, in the frame of a logistic regression model, we examined the effect of several variables on cluster memberships (more traditional or more modern attitudes of students). 
Table 1. Gender role attitudes by gender, means of the agreement scale $(N)$ (1: totally disagree, 2: disagree, 3: agree, 4: totally agree) (TERD research, 2010).

\begin{tabular}{|c|c|c|c|}
\hline Gender role attitude statements & Men & Women & ANOVA \\
\hline $\begin{array}{l}\text { The husband should significantly participate in rearing the } \\
\text { children. }\end{array}$ & $3.3(154)$ & $3.63(419)$ & $* * *$ \\
\hline If the child is ill, the father can go on sick leave. & $2.91(150)$ & $3.11(411)$ & $* *$ \\
\hline $\begin{array}{l}\text { Both women and men should participate in assuring the } \\
\text { sustenance of the family. }\end{array}$ & $3.08(154)$ & $3.51(419)$ & $* * *$ \\
\hline $\begin{array}{l}\text { The cooperation of men and women is necessary in solving } \\
\text { the problems of the family. }\end{array}$ & $3.41(154)$ & $3.75(420)$ & $* * *$ \\
\hline $\begin{array}{l}\text { The household work should be shared by both the husband } \\
\text { and the wife. }\end{array}$ & $3.11(154)$ & $3,38(420)$ & $* * *$ \\
\hline It is the task of women to do the housework. & $2.39(152)$ & $2.17(420)$ & $* *$ \\
\hline $\begin{array}{l}\text { To assure the sustenance of the family is primarily the task } \\
\text { of the husband. }\end{array}$ & $2.71(154)$ & $2.2(421)$ & $* * *$ \\
\hline $\begin{array}{l}\text { The most important decisions in the family should be made } \\
\text { by the husband. }\end{array}$ & $2.48(154)$ & $1.98(417)$ & $* * *$ \\
\hline Rearing children primarily the task of women. & $2.38(154)$ & $2.14(420)$ & $* * *$ \\
\hline If the child is ill, the mother should go on sick leave. & $2.44(153)$ & $2.09(418)$ & $* * *$ \\
\hline
\end{tabular}

In the table, $0.01<p<0.05$ is marked by *, $0.001<p<0.01$ is marked by ${ }^{* *}, p<0,001$ is marked ${ }^{* * *}$, and NS is a non-significant relation according to the ANOVA tests. The significantly higher averages are marked by grey background.

As can be seen in Table 1, men agree (but not totally), and women disagree (but not totally) with traditional attitudes. Concerning modern attitudes, men agree (but not totally), and most of the women totally agree with them. Therefore, women's attitudes are generally more modern, in accordance with our hypothesis (this will also be examined later within the frame of the logistic regression model). 
Table 2. Final cluster centres based on gender role attitudes (1: totally disagree, 2: disagree, 3: agree, 4: totally agree) (TERD research, 2010).

\begin{tabular}{|c|c|c|}
\hline Gender role attitude statements & $\begin{array}{l}\text { More modern } \\
\text { attitude cluster }\end{array}$ & $\begin{array}{l}\text { More traditional } \\
\text { attitude cluster }\end{array}$ \\
\hline $\begin{array}{l}\text { The husband should significantly participate in rearing the } \\
\text { children. }\end{array}$ & 3.73 & 3.32 \\
\hline If the child is ill, the father can go on sick leave. & 3.28 & 2.78 \\
\hline $\begin{array}{l}\text { Both women and men should participate in assuring the } \\
\text { sustenance of the family. }\end{array}$ & 3.65 & 3.10 \\
\hline $\begin{array}{l}\text { The cooperation of men and women is necessary in solv- } \\
\text { ing the problems of the family. }\end{array}$ & 3.87 & 3.43 \\
\hline $\begin{array}{l}\text { The household work should be shared by both the hus- } \\
\text { band and the wife. }\end{array}$ & 3.57 & 2.97 \\
\hline It is the task of women to do the housework. & 1.86 & 2.72 \\
\hline $\begin{array}{l}\text { To assure the sustenance of the family is primarily the task } \\
\text { of the husband. }\end{array}$ & 1.89 & 2.89 \\
\hline $\begin{array}{l}\text { The most important decisions in the family should be } \\
\text { made by the husband. }\end{array}$ & 1.80 & 2.49 \\
\hline Rearing children primarily the task of women. & 1.94 & 2.57 \\
\hline If the child is ill, the mother should go on sick leave. & 1.84 & 2.65 \\
\hline$N=$ & 309 & 239 \\
\hline
\end{tabular}

The higher cluster centre averages are marked by grey background.

Based on the results in Table 2, modern attitudes are dominant in the first cluster and traditional attitudes in the second. Concerning the five statements that represent modern attitudes, the members of the first cluster agree with them entirely, except they do not totally agree with the statement 'If the child is ill, the father can go to sick leave'. The members of the second cluster agree with these statements as well, but not totally; thus, their attitude is more traditional. Concerning the other five statements, which represent traditional attitudes, the members of the second cluster relatively agree (they agree least with the statement 'The most important decisions in the family should be made by the husband'), but the members of the first cluster disagree with all the five statements (but not totally). Therefore, generally speaking, the first cluster shows more modern attitudes, and the second shows more traditional ones. It must be mentioned that the members of the second cluster could not be described by totally traditional attitudes as they also agree with some modern attitudes; therefore, it can said that their mentality is less modern than that of the members of the first cluster. A comparison of cluster memberships shows that $56.4 \%$ of students belong to the more modern attitude cluster and $43.6 \%$ 
to the more traditional one; therefore, a large amount of students with more traditional gender role attitudes exists. This is contrary to the first hypothesis.

Table 3. Logistic regression models ${ }^{6}$ on gender role attitude cluster membership (o: more traditional, 1: more modern). Exp (B)s and significance levels (TERD research, 2010).

\begin{tabular}{l|c|c|c|c}
\hline Explanatory variables & $\begin{array}{c}1^{\text {st }} \text { model } \\
\operatorname{Exp}(\mathrm{B})\end{array}$ & $\begin{array}{c}2^{\text {nd }} \text { model } \\
\operatorname{Exp}(\mathrm{B})\end{array}$ & $\begin{array}{c}3^{\text {rd }} \text { model } \\
\operatorname{Exp}(\mathrm{B})\end{array}$ & $\begin{array}{c}4^{\text {th }} \text { model } \\
\text { Exp (B) }\end{array}$ \\
\hline GENDER & $0.26^{* * *}$ & $0.31^{* * *}$ & $0.29^{* * *}$ & $0.23^{* * *}$ \\
\hline FACTYPE & & $1.03^{* *}$ & $1.02^{*}$ & 1.01 \\
\hline EDMOTHER & & & 1.06 & 1.07 \\
\hline EDFATHER & & & 0.96 & 0.94 \\
\hline BOOKSPAR & & & $1.79^{*}$ & $1.77^{*}$ \\
\hline DURCONS & & & 1.02 & 1.04 \\
\hline FIN1OYEARS & & & 0.79 & 0.69 \\
\hline FINPROB & & & 1.34 & 0.63 \\
\hline SETTTYPE & & & & 1.36 \\
\hline RELCHURCH & & & & $0.36^{* *}$ \\
\hline RELOWN & & & $9.24 \%$ & 1.03 \\
\hline Decrease in -2LL & $6.08 \%$ & & & $11.73 \%$ \\
\hline
\end{tabular}

Significance level (Wald-statistics): $0.01<p<0.05$ is marked by $*, 0.001<p<0.01$ is marked by ${ }^{* *}$, $p<0,001$ is marked ${ }^{* * *}$, else the relation is not significant.

As can be seen in Table 3, among the students, women identify themselves with more modern gender roles than men, in accordance with our hypothesis. However, the faculty-type effect can only be partly detected. We supposed that in 'male-dominated' majors women identify themselves with more modern gender roles than in 'female-dominated' majors and that men identify themselves with more modern gender roles in 'female-dominated' majors than in 'male-dominated' majors; therefore, the more 'female-dominated' the major is, the more similar the gender role attitudes become between men and women. However, our regression results do not confirm this. When we examined

6 In the first model, we examine only the effect of gender on gender role attitudes, in the second, the effect of gender and faculty type, in the third the effect of gender, faculty type and the effect of social background variables and finally in the forth the effect gender, faculty type, social background and religiosity on gender role attitudes. We included the explanatory variables step by step, in order to examine the changes of the effects through the inclusion of other variables. For a detailed description of the variables, see the 'Methods, databases and the examined variables' section of this paper. 
crosstabs results, we found that with 'male-dominated' majors 7 both men and women identify themselves with more traditional attitudes (85\% of men and $59 \%$ of women think traditionally) but with 'female-dominated' majors these rates are only $63 \%$ and $34 \%$; therefore, $37 \%$ of men and $66 \%$ of women belong to the more modern attitude cluster. Generally speaking, with 'male-dominated' majors, $73 \%$ of students are thinking traditionally and with 'female dominated' majors only $40 \%$ of them are. The attitude of women by faculty type is rather surprising. A 'gender inappropriate' career choice does not lead to more modern attitudes among women, but it does among men; this requires further and more detailed examination in further research.

We have also supposed that students with disadvantageous social backgrounds (measured by their cultural and material capital) identify themselves with more traditional attitudes. However, based on our results, this is only partly true. There is a significant positive effect of the objective cultural capital on gender roles: the larger numbers of books owned by parents increases modern attitudes among students. Furthermore, our results show that 'regular financial problems in the family' increases modern attitudes and not traditional ones, which is in accordance with our other (alternative) hypothesis about the effect of social background. The students who might be first generation professionals (as their financial background is worse than that of others) identify themselves with more modern gender roles.

Another result is that the other social background variables (e.g. the education of parents) have no effect on the gender role attitudes; therefore, generally speaking, the effect of family background is not as pronounced as we expected.

Our next hypothesis, i.e. that students who live in villages have more traditional gender role attitudes than the others, was not confirmed either. The reason for this could be that most students coming from villages live in the setting of the university (i.e. in the city) during their studies, and they are exposed to more modern attitudes. The other reason could be the media effect on gender role attitudes. Nowadays, more modern attitudes are popular in villages due to the mediation of the mass media.

Our previous results (Fényes, 2012), based on the examination of the same database, showed that the qualification of fathers and the type of the settlement are better for men in the sample, and financial problems in the men's families are less frequent, so we supposed in this paper that the better social

7 In our research (in crosstab results), 'male-dominated' majors were engineering, agrarian and informatics. Only 70 students are studying at these faculties ( $12 \%$ of the sample), and here the percentage of females is less than $60 \%$ (the overall rate of females in the sample is $73 \%$ ). 
background of men could moderate their more traditional gender role attitudes compared to women. However, our results show that when we control the effect of the better social background of men, they can be described as having slightly more traditional attitudes, contrary to our hypothesis. The reason for this (as we have seen before) is that the less frequent financial problems (and this is the case in the families of men) increase the acceptance of the traditional attitudes about gender roles and that the types of the settlement and fathers' qualification have no effect on gender role attitudes.

Our last hypothesis was that religious students are characterised by more traditional gender role attitudes. As our results show, churchly religious students (who strictly follow the instructions of their church) think more traditionally about gender roles than the others, but those who are religious in their own way do not. The reason for this could be that being religious in one's own way is a more modern type of religiosity, so such students' gender role attitudes are also more modern. ${ }^{8}$

\section{Summary and conclusions}

We found that nearly half of the students identify themselves with traditional attitudes concerning gender roles, but (as we have also demonstrated) the members of the traditional cluster could not be described by totally traditional attitudes, just that their way of thinking is less modern than that of the members of the first cluster. In the theoretical part of the paper, it had been shown that the traditional attitude concerning gender role is a Central-Eastern European phenomenon. However, we have also supposed that the higher level of education increases modern attitudes, so among the whole population the attitudes could be even more traditional than among the students examined.

Our logistic regression results show that in, accordance with our hypothesis, women identify themselves with more modern gender roles than men among the students examined, but the faculty-type effect can only be partly detected. We have found that with 'male-dominated' majors both men and women identify themselves with more traditional attitudes and that with 'female-dominated' majors the students' attitudes are more modern; this needs further analysis.

The effect of the social background of students was contradictory. As we supposed, a larger number of books owned by parents increased modern

8 When we included the religiosity of parents (regularity of churchgoing and praying) in our model, it reveals no significant relationship with students' gender role attitudes. Our other result is that girls think even more modernly if the effect of religiosity (church-related) is separated, as there are more regular churchgoers among them. 
attitudes (cultural capital effect), but we found as well that 'regular financial problems in the family' also increased modern attitudes, and not traditional ones. This latter result is in accordance with our alternative social mobility hypothesis about the effect of social background. A further result is that students who live in villages are not thinking more traditionally about gender roles than the others, which may be due to the fact that they live in cities during the semester. Our final result shows that traditionally religious students' ways of thinking are more traditional about gender roles, but for those who are religious in their own way (a more modern type of religiosity) gender role attitudes are less traditional.

All things considered, the effect of the students' social background, locality type and religiosity on their gender role attitudes is not as pronounced as we had expected; therefore, we can suppose that the effect of high school or university and the effect of peer groups (secondary socialisation effect) could be more influential in the formation of gender role attitudes. However, as stated in the theoretical part of our paper, gender role attitudes (measured by the evaluation of women's labour market activity) are relatively independent of the educational process and attainment. Therefore, based on these results, we make the following proposals regarding to how higher education can more effectively shape the gender role attitudes of students and how students could be aware of their attitudes, and shape their own education.

The effect of education on gender roles depends on several factors and can be different between countries, periods, type of institutions and faculties. As we have seen, at the 'female-dominated' faculties (e.g. the faculty of arts), the gender role attitudes of students are much more modern than at 'male-dominated' faculties (e.g. engineering or IT); and the attitudes of women are more modern with 'female-dominated' majors and less modern with 'male-dominated' majors, which is an intriguing result, and one that needs further research.

We think (based on our finding that in higher education students' attitudes about gender roles are not necessary modern) that the mediation of more modern attitudes is necessary in higher education. ${ }^{9}$ As shown by our previous results, the fact that modern attitudes are popular among students in words but not yet in deeds, and our present finding that the students with more traditional

9 This is our personal suggestion, as sociology is not a normative science and can not theoretically justify which gender role attitude is more beneficial for the society. We think that the flow of women into the labor market is a positive fact, and this necessarily has an effect on gender role attitudes. Women have taken on additional, nontraditional roles. We also believe (as opposed to radical feminist views) that family is an important institution, and should not be destroyed due to the women's labor market participation. If the modern (but not radical) gender role attitudes are more popular among males and females, this helps women to fulfill their dual responsibilities in the family and in the labor market. 
attitudes do not totally reject modern attitudes both partly contribute to this process.

In order to increase the acceptance of modern attitudes among students, higher education institutions should present a wide variety in majors and courses (supply side). Additionally, more modern gender role attitudes should be presented in the curricula and in course books, and in the everyday life of students (during the communication with teachers and among peers). Teachers should encourage students to choose not only gender-appropriate majors, but also should encourage women to go to 'male-dominated' faculties and men to 'female-dominated' faculties. As we have seen previously, based on the empirical findings, the attitudes of women are more modern concerning gender roles than men's are. Furthermore, as there are increasing numbers of women on faculty staff, female lecturers should mediate their more modern gender role attitudes to students.

It must also be mentioned that the effect of education is not a one-way transfer of knowledge. The curriculum should follow the expectations of students, so students also shape the process of education. Students should come to be aware of their gender role attitudes, and should know how they can change these attitudes. In order to achieve this, women's studies courses should be included in the curriculum in most study areas. This is particularly pertinent in teacher training, as the teachers will form and mediate the attitudes of students. Our other suggestion is that as the position of women in higher education could serve as role models, the employment of more woman researchers, professors and leaders in higher education would be highly favourable.

In general, the current education policy should decide in which field the intervention would be the most efficient, and should also take into consideration the effects of other socialisation agents' on the gender role formation of students.

Concerning our empirical results, further research is needed to examine gender role attitudes of students' based on other statements (which were mentioned in the literature) and to perform further cluster analyses. We can also make a deeper analysis about the faculty-type effect, possibly with multilevel statistical methods.

As a final point, further qualitative interviews or focus group interviews could be made among students about gender roles (we have already made interviews with students at the department of librarian and informatics science, where we examined the gender role attitudes of men and women studying in this particular area; see the results at Bujdosó \& Fényes, 2014). 


\section{References}

Adler, P. A., Kless, S. J., \& Adler, P. (1992). Socialization to Gender Roles. Popularity among Elementary School Boys and Girls. Sociology of Education, 65(3), 169-187.

Astin, A. W. (1977). Four Critical Years: Effects of College on Beliefs, Attitudes and Knowledge. San Francisco: Jossey-Bass

Astin, H. S., \& Kent, L. (1983). Gender-Roles in Transition: Research and Policy implications for Higher Education. The Journal of Higher Education, 54(3), 309-324.

Bielby, W. T., \& Bielby, D. D. (1992). I Will Follow Him: Family Ties, Gender-role Beliefs and Reluctance to Relocate for a Better Job. American Journal of Sociology, 97(5), 1241-1267.

Blackstone, A. M. (2003). Gender Roles and Society. In J. M. Miller, R. M. Lerner, \& L. B. Schiamberg (Eds.), Human Ecology: An Encyclopedia of Children, Families, Communities, and Environments (pp. 335-338). Santa Barbara, CA: ABC-CLIO.

Brewster, K. L., \& Padavic, I. (2000). Change in Gender-Ideology, 1977-1996: The Contributions of Intracohort Change and Population Turnover. Journal of Marriage and Family, 62(2), 477-487. Buda B. (1985). Női szerep - női szocializáció - női identitás. [Women’s Role - Women’s Socialisation - Women’s Identity]. In K. Koncz (Ed.), Nők és férfiak. Hiedelmek, tények. [Women and Men. Beliefs and Facts] (pp. 93-110). Budapest: Magyar Nők Országos Tanácsa, Kossuth Könyvkiadó. Bujdosó, Gy., \& Fényes, H. (2014). Investigating Gender Issues in a Population of Library and Information Science Students (to be published).

Fényes, H. (2010a). A nemi sajátosságok különbségének vizsgálata az oktatásban. A nök hátrányainak felszámolódása? [Gender Differences in Education. The Elimination of the Disadvantages of Women?]. Debrecen: Debreceni Egyetemi Kiadó.

Fényes, H. (2010b). School Efficiency of Boys and Girls in a Borderland Region of Hungary. Review of Sociology, 6(1), 51-77.

Fényes, H. (2012). Gender Inequalities in Higher Education. Evidence from the „Partium” Region. Corvinus Journal of Sociology and Social Policy, 3(1), 3-34.

Fortin, N. M. (2005). Gender Role Attitudes and the Labor-Market Outcomes of Women across OECD Countries. Oxford Review of Economic Policy, 21(3), 416-438.

Frey, M. (2001). Nők és férfiak a munkaerőpiacon. [Women and Men on the Labor Market]. In I. Nagy, T. né Pongrácz, \& I. Gy. Tóth (Eds.), Szerepváltozások: Jelentés a nők és férfiak helyzetéről 2001. [Changing Roles: Report about the Situation of Women and Man. 2001] (pp. 9-30). Budapest, TÁRKI.

Gregor, A. (2008). „Ha volna két életem...” A szerepkonfliktusból fakadó feszültségek a nyugateurópai, a posztszocialista országok- és az USA-beli nők között. [If I had Two Lives... Tension Emerging from Role-Conflicts among Western-European, Post-Socialist and US Women]. Szociológiai Szemle, (2), 87-110.

H. Sas, J. (1984). Nőies nők és férfias férfiak. A nőkkel és férfiakkal kapcsolatos sztereotípiák élete, eredete és szocializációja. [Feminine Women and Masculine Men. The Life, Origin and Socialisation 
of Stereotypes related to Women and Men]. Budapest: Akadémiai Kiadó.

Háber, J., \& H. Sas, J. (1980). Tankönyvszagú világ. [The World Presented by Course-books].

Budapest: Akadémiai Kiadó.

Inglehart, R., \& Norris, P. (2003). Rising Tide. Gender Equality and Cultural Change around the

World. Cambridge: Cambridge University Press.

Kaufman, G., \& Uhlenberg, P. (2000). The Influence of Parenthood on the Work Effort of Married men and Women. Social Forces, 78(3), 931-947.

Kereszty, O. (2005). A társadalmi nemek reprezentációjának vizsgálata tankönyvekben. [The

Examination of Gender Representation in Textbooks]. Könyv és Nevelés, (szeptember), 56-67.

Laki, L. et al. (2008). Magyar Nemzeti Ifjúságpolitikai Riport. [Hungarian National Youth-Policy

Report]. MTA Politikai Tudományok Intézete, Európa Tanács Vitaanyag.

Parsons, T., \& Bales, R. F. (Eds.) (1955). Family Socialization and Interaction Process. New York, Free

Press

Pongrácz, T.né (2005). Nemi szerepek társadalmi megítélése. Egy nemzetközi összehasonlító vizsgálat tapasztalatai. [The Social Evaluation of Gender Roles. The Results of an International Comparative Research]. In I. Nagy, T.né Pongrácz, \& I. Gy. Tóth (Eds.), Szerepváltozások. Jelentés a nök és férfiak helyzetéröl 2005. [Changing Roles: Report on the Situation of Women and Men, 2005] (73-86. old). Budapest: TÁRKI Ifjúsági, Családügyi, Szociális és Esélyegyenlőségi Minisztérium. Pongrácz, T.né, \& Molnár, S. E. (2011). Nemi szerepek és a közvélemény változásának kölcsönhatása.

[The Interaction of Gender Roles and the Changes in Public Opinions]. In I. Nagy I. \& T.né Pongrácz (eds.), Szerepváltozások. Jelentés a nök és férfiak helyzetéröl 2011. [Changing Roles: Report on the Situation of Women and Men, 2011] (pp. 192-206). Budapest: TÁRKI.

Pukánszky, B. (2006). A nőnevelés évezredei. Fejezetek a lányok nevelésének történetéböl. [The Thousand Years of Women's Education. Chapters from the History of Education of Girls]. Budapest: Gondolat Kiadó.

Rice, T. W., \& Coates, D. L. (1995). Gender Role Attitudes in the Southern United States. Gender and Society, 9(6), 744-756.

Saha, L. J. (Ed.) (1997). International Encyclopaedia of Sociology of Education. Oxford: Pergamon

Press

Schadt, M. (2003). „Feltörekvő dolgozó nö” Nők az ötevenes években. [Ambitious Working Woman.

Women in the 1950s]. Pécs: Pannónia Könyvek, Pro Pannonia Kiadói Alapítvány.

Scott, J. (2006). Family and Gender Roles: How Attitudes Are Changing? GeNet Working Paper No. 21, University of Valencia, Spain.

Somlai, P. (1997). Szocializáció. A kulturális átörökítés és a társadalmi beilleszkedés folyamata.

[Socialisation. The Process of Cultural Transmission and Social Adoption]. Budapest: Corvina Kiadó Szabó, L. T. (1988). A „rejtett tanterv”. [Hidden Curriculum]. Budapest: Magvető Kiadó.

Tallichet, S. E., \& Willits, F. K. (1986). Gender-Role Attitude Change of Young Women: Influential Factors from a Panel Study. Social Psychology Quarterly, 49(3), 219-227.

Tinklin, T., Croxford, L., Ducklin, A., \& Frame, B. (2005). Gender and Attitudes to Work and Family 
Roles: The View of Young People at the Millennium. Gender and Education, 17(2), 129-142.

Thornton, A., \& Young-DeMarco, L. (2001). Four Decades of Trends in Attitudes Toward Family Issues in the United States: The 1960s Through the 1990s. Journal of Marriage and Family, 63(November), 1009-1037.

Vella, F. (1994). Gender Roles and Human Capital Investment: The Relationship between Traditional Attitudes and Female Labor Market Performance. Economica, 61, 191-211.

Zuo, J., \& Tang, S. (2000). Breadwinner Status and Gender Ideologies of Men and Women regarding Family Roles. Sociological Perspectives, 43(1), 29-43.

\section{Biographical note}

Hajnalka Fényes (habil, $\mathrm{PhD}$ ) is an associate professor at the University of Debrecen (Hungary) at the Department of Sociology and Social Policy and an active researcher in the Center of Higher Education Research and Development (Hungary). Her resent research fields: gender differences in higher education, social mobility in higher education, methodology of sociology, volunteering among higher education students. She is involved in several national and international research projects on these topics. She has 44 scientific publications and has 108 independent citations on them. She has presented her works in international conferences and published in various international scientific journals. 